\title{
Information estimate of natural geosystem preservation in geoconstruction
}

\author{
Larisa Svatovskaya ${ }^{1, *}$, Kseniia Mikhailova ${ }^{1}$, Tatyana Supeliuk $^{1}$, and Anatoliy Kniazev ${ }^{1}$ \\ ${ }^{1}$ Emperor Alexander I St. Petersburg State Transport University, 9 Moskovsky pr., St. Petersburg, \\ 190031, Russia
}

\begin{abstract}
The area of the research is natural geosystem preservation in geoconstruction. The aim of the research is introduction of information assessment of preservaton level using total geoecological parameter in geoconstruction. Three features were chosen as the main geoecological information features of the estimate, prediction and geosystem preservation management, they are: natural raw materials consumption, fuel consumption and useful properties of a mineral geostructure with the end of the life-cycle. Rating method is suggested as a method of the rasearch;it includes conversion of the properties, using certain mathimatical operations into dimensionless values named index of properties. By determining weight factors with the help of expert assessment and bydetermining the sum of productions of indices and coefficients as total geoecological parameter, the study shows the relationship of the latter with the values of the real consumption of natural raw materials, fuel and useful properties of wastes with the end of the life-cycle of a geostructure. Also the study suggests the achieved levels of the preservation and predicted increase of the level takinginto consideration the total geoecological parameter. The results can be used for estimate of any geotechnology in the preservation aspect.
\end{abstract}

\section{Introduction}

The area of the reaserch is preservation of the natural geoenvironment in geoconstruction to provide life for present and future generation of people.

The article assesses geoecological properties of structure elements of construction geoobjects and their total values taking into consideration the relationship of raw material, $\mathrm{P}_{\mathrm{r}}$, energy components, $\mathrm{P}_{\lambda}$, and useful properties of mineral wastes obtained with the end of life cycle, $\mathrm{P}_{\text {upn }}$ [1-5]. Also the arcticle analyses the most informative geoecoprotective properties of mineral cement-containing geostructures as the most widely-used in geoconstruction activiies [6-10].

The aim of the research is to introduce the total information geoecological parameter (GEP) in geoconstruction which informs about the achieved and predicted level of the natural geoenvironment preservation and about the possibility to increase the level of preservation, so, the total geoecological parameter (GEP) is the function of the properties:

\footnotetext{
* Corresponding author: lbsvatovskaya@ yandex.ru
} 


$$
G E P=f\left(P_{r}+P_{\lambda}+P_{u p w)}\right.
$$

\section{Methods}

The rating method of weight factors was chosen to calculate Such kind of methods applied in green civil construction technologies.

This method makes it possible to assess the propeties charecterized by different measurement units on the uniform scale. Using certain mathematical operations the properties are converted into dimensionless values, then using further mathematical operations GEP is calculated. It is supposed that the higher the GEP values of a geoconstruction are, the higher the level of protection and preservation of the natural geosystems is [12-17].

According to the method, for each of the 3 components of the properties has been found the means of converting its value up to the range from 0 to 1 . For that purpose it was specified the interval of the values of the property component - the best and the worst value from the specified interval. The best value is a normalized value within an open range from 0 to 1 . This range is called the range of indices, i.e. we have geoecoloical properties and indices of these properties.

Therefore, mathematical operations make it possible to present a geoecological property as a dimensionless value which is called the property index and is calculated from the graph, and then, considering the weight factor of significance, it becomes a component for GEP calculation according to the formula (1).

The weight factor of significance is formed in percents determined by expert assessment. And the weight sum of all the properties should be $100 \%$. Then GEP is calculated as the sum of components repersented by the product of the property weight significance and the geoecological property index, found grafically. Geoecological property with the best value has the property index equals 1 , if the property has the worst value the index will be 0 .

GEP gradation is by 100-point scale. 1 point is accepted to be a knowingly low indicator, 100 points - maximum one. The sum of the weight factors of all the parameters, as it was mentioned before, should be 100 . So:

$$
G E P=\sum k_{i} \cdot i P_{i}
$$

where $k_{i}$ - weight factor of $i$-property;

$i P_{i}-$ index of $i$-property under consideration.

\section{Results and discussion}

Taking into consideration the expert assessment each of the properties was given the significance in percent, then the total geoecological parameter (GEP) was calculated according to the formula (2).The obtained resultsand GEP parameter are shown in Table 1.

The data in the table 1 shows that the GEP values differ by more than an order depending on geoecological properties.

According to the values of table 1 the highest GEP value $-83,6$ belongs to a geostructural building element of $1 \mathrm{~m}^{3}$ volume and D500 density. The research analyzed fuel and energy consumption through time (if we accept that 50 years is envisaged life cycle) for $1 \mathrm{~m}^{3}$ (geostructures with different GEP values). 
Table 1. Geoecological parameters taking into consideration the indices of geoecological properties and their weight factors.

\begin{tabular}{|c|c|c|c|c|}
\hline \multirow{2}{*}{$\begin{array}{c}\text { Building } \\
\text { geostructure, } \\
\text { density } \mathrm{kg} / \mathrm{m}^{3}\end{array}$} & \multicolumn{3}{|c|}{$\begin{array}{l}\text { Indices of geoecological properties and their weight factors of } \\
\text { significance }(\%)\end{array}$} & \multirow{2}{*}{$\begin{array}{c}\text { Total } \\
\text { geoecological } \\
\text { assessmnet, GEP } \\
\text { parameter } \\
\text { GEP }\end{array}$} \\
\hline & $\begin{array}{c}\text { Resource } \\
\text { conservation, } i \mathrm{P}_{r} \\
(40 \%)\end{array}$ & $\begin{array}{c}\text { Energy preservation in } \\
\text { operation, } i \mathrm{P}_{\lambda}(40 \%)\end{array}$ & $\begin{array}{l}\text { Useful properties of } \\
\text { wastes, } i \mathrm{P}_{\text {upw }}(20 \%)\end{array}$ & \\
\hline D2000 & 0 & 0 & 0,24 & 4,8 \\
\hline D1900 & 0,31 & 0,14 & 0,29 & 23,8 \\
\hline D600 & 0,64 & 0,84 & 0,9 & 80,4 \\
\hline D500 & 0,72 & 0,87 & 1 & 83,6 \\
\hline
\end{tabular}

According to the values of table 1 the highest GEP value $-83,6$ belongs to a geostructural building element of $1 \mathrm{~m}^{3}$ volume and D500 density. The research analyzed fuel and energy consumption through time (if we accept that 50 years is envisaged life cycle) for $1 \mathrm{~m}^{3}$ (geostructures with different GEP values).

Known formula (3) was used to analyze the relationship of GEP of a building geoelement of the $1 \mathrm{~m}^{3}$ structure with the fuel consumption

$$
Q_{h l}=k \cdot F \cdot d t
$$

where $Q_{\mathrm{hl}}$ - heat loss by a geostructure;

$F$ - square (of a structure), $\mathrm{m}^{2}$;

$d t$ - difference of operating temperatures (external and internal);

$k$-heat transfer coefficient of a barrier structure.

$$
k=1 / \lambda_{\text {int }}+\sum \beta_{i} / \lambda_{i}+1 / \lambda_{\text {ext }}
$$

where $\lambda_{\text {int }}, \lambda_{\text {ext }}-$ heat emission coefficients of internal and external surfaces of a structure, $\mathrm{W} /\left(\mathrm{m}^{2} \cdot \mathrm{C}\right)$

$\lambda_{\mathrm{i}}$-thermal conductivity coefficient of $i$-layer of the material, $\mathrm{W} /(\mathrm{m} \cdot \mathrm{C})$;

$\beta_{\mathrm{i}}-$ thickness of $i$-layer of a structure, $\mathrm{m}$.

For further calculations we used energy unit conversion:

$$
1 \text { t.o.e. }=11,63 \mathrm{MW} / \mathrm{h}=1231 \mathrm{~m}^{3} \text { of gas }=1,04 \text { t of fuel oil }=3,04 \mathrm{n} \text { of coal }
$$

where $\lambda_{\text {int }}, \lambda_{\text {ext }}-$ heat emission coefficients of internal and external surfaces of a structure, $\mathrm{W} /\left(\mathrm{m}^{2} \cdot \mathrm{C}\right)$

$\lambda_{\mathrm{i}}$-thermal conductivity coefficient of $i$-layer of the material, $\mathrm{W} /(\mathrm{m} \cdot \mathrm{C})$;

$\beta_{\mathrm{i}}-$ thickness of $i$-layer of a structure, $\mathrm{m}$.

For further calculations we used energy unit conversion:

$$
\text { 1 t.o.e. }=11,63 \mathrm{MW} / \mathrm{h}=1231 \mathrm{~m}^{3} \text { of gas }=1,04 \text { t of fuel oil }=3,04 \mathrm{n} \text { of coal }
$$

Where t.o.e.- ton of oil equivalent.

The results of the research, which are in accordance with the ideas in the works [18-22] makes it possible to claim that preservation levels with GEP from 80,4 and higher meet the requirements of the geoenvironment protection. Preservation levels with GEP lower than 80,4 don't keep the natural environment productive for the life of people generations.

If the relationships of GEP with consumption of natural raw materials, fuel and waste useful properties are true as an information platform of new geoecoprotective technologies, 
it is possible to set acertaincourse to predict the protection of natural-technogenic systems of GEP. It has been shown, that taking into consideration GEP values it is possible to predict the protection by considering fuel consumption - the higher the GEP value of a building geostructure element is, the lower the fuel consumption is throughout the life cycle of an object. But it is possible to control GEP values, increasing, for example, resource conservation: the less natural raw materials have been used, the higher GEP value is. Also it is possible to reduce the share of natural raw materials by using technogenic raw materials instead of natural ones, or by lowering the density (air dilution) of a construction geoelement.

To test these results it has been used special technogenic raw material (nepheline slime) which contributes to energy conservation (for construction geoelement of 83,6 GEP) and to air dilution at the same time.

Calculations have been done in the construction of a geoecological structure, total volume of construction elements $500 \mathrm{~m}^{3}$ with improved geoecological features - replacement of some raw materials by special technogenic ones (nepheline slime) and using D200 foamed concrete as heater. Tables 2,3,4,5 show the obtained data.

Table 2. Geoecological properties of geostructure of average density D500.

\begin{tabular}{|c|c|c|c|}
\hline $\begin{array}{c}\text { Geostructure of a } \\
\text { construction object } 1 \mathrm{~m}^{3} \\
\left(\text { density, } \mathrm{kg} / \mathrm{m}^{3}\right)\end{array}$ & $\begin{array}{c}\text { Resource } \\
\text { Intensity } \\
\mathrm{P}_{\mathrm{r}}, \mathrm{kg} / \mathrm{m}^{3}\end{array}$ & $\begin{array}{c}\text { Energy preservation } \\
\mathrm{P} \lambda, \mathrm{W}(\mathrm{m} \cdot \mathrm{C})\end{array}$ & $\begin{array}{c}\text { Useful properties of } \\
\text { wastes } \\
\mathrm{Pupw}, \mathrm{by} \mathrm{Fe}(\mathrm{III})\end{array}$ \\
\hline $\begin{array}{c}\text { D500}(\mathrm{control}) \\
\text { D500 with technogenic } \\
\text { raw materials use }\end{array}$ & 0,50 & 0,12 & 3,6 \\
\hline D200 & 0,42 & 0,11 & 4,3 \\
\hline
\end{tabular}

Table 3. Index values of geoecological properties of geostructures(from graph).

\begin{tabular}{|c|c|c|c|c|}
\hline \multirow{2}{*}{$\begin{array}{l}\text { Geostructure of a } \\
\text { construction object } 1 \\
\left.\mathrm{~m}^{3} \text { (density, } \mathrm{kg} / \mathrm{m}^{3}\right)\end{array}$} & \multicolumn{3}{|c|}{ Index values of geoecological properties } & \multirow[b]{2}{*}{$\begin{array}{c}\text { Total } \\
\text { geoecological } \\
\text { assessmnet (GEP } \\
\text { parameter, } \\
\text { formula 2) }\end{array}$} \\
\hline & $\begin{array}{c}\text { Resource } \\
\text { conservation, } \\
i \mathrm{P}_{r}\end{array}$ & $\begin{array}{c}\text { Energy } \\
\text { preservation } \\
i \mathrm{P}_{\lambda}\end{array}$ & $\begin{array}{c}\text { Useful } \\
\text { properties of } \\
\text { wastes } i \mathrm{P}_{\text {upw }}\end{array}$ & \\
\hline D500(control) & 0,72 & 0,84 & 0,9 & 83,6 \\
\hline $\begin{array}{l}\text { D500 with } \\
\text { technogenic raw } \\
\text { materials use }\end{array}$ & 0,81 & 0,86 & 0,94 & 85,6 \\
\hline D200 & 0,88 & 0,92 & 1 & 92 \\
\hline
\end{tabular}

Table 4. Relationship of GEP and resource conservation index of a construction geostructure with technogenic product (nepheline slime) for different volumes.

\begin{tabular}{|c|c|c|c|c|c|c|}
\hline \multirow{3}{*}{ Name } & \multicolumn{4}{|c|}{ Total geoecological assessment (GEP parameter) } & \multirow{3}{*}{$\Delta 1 \mathrm{~m}^{3}$} & \multirow{3}{*}{$\Delta 500 \mathrm{~m}^{3}$} \\
\hline & \multicolumn{2}{|c|}{83,6} & \multicolumn{2}{|c|}{85,6} & & \\
\hline & $1 \mathrm{~m}^{3}$ & $500 \mathrm{~m}^{3}$ & $1 \mathrm{~m}^{3}$ & $500 \mathrm{~m}^{3}$ & & \\
\hline $\begin{array}{c}\text { Resources } \\
\mathrm{t} / \mathrm{m}^{3}\end{array}$ & 0,50 & 250 & 0,38 & 190 & 0,12 & 60 \\
\hline
\end{tabular}


Table 5. Relationship of GEP with energy resource use in different construction geostructures.

\begin{tabular}{|c|c|c|c|c|}
\hline \multirow{2}{*}{$\begin{array}{c}\text { Resource } \\
\text { consumption }\end{array}$} & \multirow{2}{*}{$\begin{array}{c}\text { Unit of } \\
\text { measurement }\end{array}$} & \multirow{2}{*}{$\begin{array}{c}\text { Volume of } \\
\text { building } \\
\text { geostructure, } \mathrm{m}^{3}\end{array}$} & \multicolumn{2}{|c|}{$\begin{array}{c}\text { Total geoecological assessment, } \\
\text { GEP parameter }\end{array}$} \\
\cline { 4 - 5 } & & 1 & 1 year & 50 years \\
\cline { 4 - 5 } $\begin{array}{c}\text { Electric } \\
\text { power }\end{array}$ & $\mathrm{MW}$ & 10 & 0,32 & 16 \\
\cline { 3 - 5 } & $\mathrm{MW}$ & 1 & 3,2 & 160 \\
\hline \multirow{2}{*}{ Natural gas } & thousand $\mathrm{m}^{3}$ & 10 & 0,04 & 2 \\
\cline { 2 - 5 } & thousand $\mathrm{m}^{3}$ & 1 & 0,4 & 20 \\
\hline \multirow{2}{*}{ Fuel oil } & $\mathrm{kg}$ & 10 & 0,03 & 1,5 \\
\cline { 2 - 5 } & $\mathrm{t}$ & 1 & 0,3 & 15 \\
\hline \multirow{2}{*}{ Coal } & $\mathrm{t}$ & 10 & 0,9 & 45 \\
\cline { 2 - 5 } & $\mathrm{t}$ & & & \\
\hline
\end{tabular}

Based on the calculations the building geostructure has been suggested with total volume $10 \mathrm{~m}^{3}$, square $40 \mathrm{~m}^{2}$ with GEP $=92$. This structure predicts saving fuel and energy resources throughout the whole life cycle of the structure element (50 years) (see Table 6).

Table 6. Predictable saving of energy and natural fuel per $1 \mathrm{~m}^{3}$ of geostructure.

\begin{tabular}{|c|c|c|c|c|c|}
\hline \multirow{2}{*}{ GEP increase } & $\begin{array}{c}\text { Geostructure } \\
\text { element volume, } \\
\mathrm{m}^{3}\end{array}$ & \multicolumn{4}{|c|}{ Saving throughout life cycle } \\
\cline { 3 - 6 } & 10 & $1,4 \cdot 10^{2}$ & $13 \cdot 10^{3}$ & $1 \cdot 10$ & $3 \cdot 10$ \\
\hline $\begin{array}{c}\text { From 83,6 to } \\
92\end{array}$ & 10 & Gas, $\mathrm{m}^{3}$ & Fuel oil, $\mathrm{t}$ & Coal, $\mathrm{t}$ \\
\hline
\end{tabular}

\section{Conclusions}

1. For information assessment of natural geosystem preservation a total geoecological parameter (GEP) has beensuggested, which includes the system properties of natural raw materials and fuel consumption as well as useful properties of a mineral structure with the end of its life cycle.

2. To calculate the total preservation parameter (GEP) the research suggests using the rating method which includes the conversion of properties into dimensionless indices with determination of weight factors of the properties. The study gives the numerical values characterizing the levels of geosystem preservation: at GEP values less than 80 the productivity of a system is not provided.

3. The article shows a possibility to increase the preservation level taking into consideration the influence on the parameter.

\section{References}

1. L.B.Svatovskaya, A.A. Kabanov,M.M. Sychov, IOP Conference Series: Earth and Environmental Science. 90. 1755-1315 (2017) DOI: 10.1088/1755-1315/90/1/012010

2. L.B.Svatovskaya, A.A. Kabanov, M.M. Sychov, IOP Conference Series: Earth and Environmental Science. 90, 1755-1315, 012009 (2017) DOI: 10.1088/17551315/90/1/012009

3. L.B.Svatovskaya, A.A. Kabanov, M.M. Sychov, Procedia Engineering. 189, 398-403 (2017) DOI:10.1016/j.proeng.2017.05.063 
4. L.B. Svatovskaya, O.V. Urov, A.A. Kabanov, Procedia Engineering, 189, 454-458 (2017) DOI: 10.1016/j.proeng.2017.05.073

5. L.B. Svatovskaya, M.V. Shershneva,M.M. Baidarashvili,N.I. Yakimova, A.V. Khitrov, Proc. of the Int. Conf. on Sustainable Waste Management and Recycling: Construction Demolition Waste, London 199-203 (2004)

6. L.B. Svatovskaya,A.S. Sakharova, M.M. Baidarashvilly, A.V. Petriaev, Proc.of the 14th Int. Conf. of Int. Association for Computer Methods and Recent Advances in Geomechanics, Kyoto, 152 (2014)

7. A.M. Sychova,L.B. Svatovskaya, S.V. Mjakin,I.V. Vasiljeva, Modification of fillers for cements (Book Chapter), Electron Beam Modification of Solids: Mechanisms, Common Features and Promising Applications, 35-37 (2009)

8. A.M. Sychova, L.B. Svatovskaya, S.V. Mjakin,I.V. Vasiljeva, Activation of aqueous phase at cement and concrete solidification (Book Chapter), Electron Beam Modification of Solids: Mechanisms, Common Features and Promising Applications, 39-47 (2009)

9. L.L. Maslennikova, L.B. Svatovskaya, S.V. Mjakin,I.V. Vasiljeva, Activation of reactions at solid-solid interfaces. Improvement of ceramics materials (Book Chapter), Electron Beam Modification of Solids: Mechanisms, Common Features and Promising Applications, 57-61 (2009)

10. L,B. Svatovskaya, N.I. Yakimova, O.Y. Trunskaya, E.V. Rusanova, N.B. Krylova, Proc. of the Int. Conf. on Sustainable Waste Management and Recycling: Construction Demolition Waste, London (2004)

11. A.M. Sychova,A. Solomahin, V. Kotovich, L.B. Svatovskaya, Y. Kamenev, E3S Web of Conferences 33, 02058 (2018) DOI: https://doi.org/10.1051/e3sconf/20183302058

12. N. Gusev, L.B. Svatovskaya, A. Kucherenko, E3S Web of Conferences 33, 02069 (2018) DOI: https://doi.org/10.1051/e3sconf/20183302069

13. A. Sychova,M. Sychov, E. Rusanova, Procedia Engineering, 189, 681-687. (2017) DOI: 10.1016/j.proeng.2017.05.108

14. A. Sychova, A. Solomahin, A. Hitrov, Procedia Engineering, 189, 688-694. (2017) DOI: 10.1016/j.proeng.2017.05.109

15. A. Kavetsky, G. Yakubova, M. Sychov, Q. Lin, et.al. Tritium Charged Capacitor, Nuclear Science and Engineering. 159, 321-329 (2008)

16. A.G. Kavetsky,S.P. Meleshkov, M.M. Sychov, Conversion of radioactive decay energy to electricity, Polymers, Phosphors and Voltaics for Radioisotope Microbatteries (CRC Press, 2002)

17. M.M. Sychov, Semiconductors, 40, 9, 1016-1020 (2006)

18. V.V. Bakhmetyev, S.V. Mjakin, V.G. Korsakov, A.M. Abyzov,and M.M. Sychov, Glass Physics and Chemistry, 37(5), 549-554 (2011)

19. M.M. Sychov,K.A. Ogurtsov,V.T. Lebedev,Yu.V. et. al. Semiconductors, 46, 5, 696700 (2012)

20. M.V. Gravit, V.I. Gumenjuk, M.M. Sychov,O. Nedyshkin, Procedia Engineering. 117 $119-125$ (2015)

21. S.V. Mjakin,T.S. Minakova,V.V. Bakhmetyev, M.M. Sychov, Russian Journal of Physical Chemistry 90, Issue 1, 240-245 (2016)

22. S.V. Myakin, M.M. Sychov, E.S. Vasina, et. al. Glass Physics and Chemistry, 40(1), 97-98 (2014) 